\section{Milk consumption, dietary calcium intake and nutrient patterns from adolescence to early adulthood and its effect on bone mass: the 1993 Pelotas (Brazil) birth cohort}

\author{
Consumo de leite, ingestão dietética de cálcio e \\ padrões de nutrientes desde a adolescência até \\ o início da idade adulta e o efeito sobre a massa \\ óssea: a coorte de nascimento de 1993 \\ de Pelotas, Rio Grande do Sul, Brasil
}

\section{Consumo de leche, ingestión dietética de calcio y patrones nutricionales desde la adolescencia hasta el inicio de la edad adulta y su efecto en la masa ósea: cohorte de nacimiento de 1993 en Pelotas, Rio Grande do Sul, Brasil}

\begin{abstract}
The objective of this study is to evaluate the effect of milk consumption, dietary calcium intake and nutrient patterns (bone-friendly and unfriendly patterns) from late adolescence to early adulthood, on bone at 22 years of age. Cross-sectional analysis was performed with 3,109 participants from 1993 Pelotas (Brazil) birth cohort in the follow-ups of 18 and 22 years of age. Bone mineral density (BMD) of the lumbar spine, right femur and whole body were assessed at 22 years using a dual-energy X-ray absorptiometry (DXA). The exposure variables (dietary calcium, milk and nutrient patterns) were created by combining the consumption frequencies between the two follow-ups (always low, moderate, high, increase or decrease). Multiple linear regressions were performed, stratified by sex. In the right femur site, men classified into the "always high" (mean $\left.=1.148 \mathrm{~g} / \mathrm{cm}^{2} ; 95 \% \mathrm{CI}: 1.116 ; 1.181\right)$ and "increased" categories of milk consumption (mean = 1.154g/ $\mathrm{cm}^{2} ; 95 \% \mathrm{CI}: 1.135$; 1.174 ) presented a slightly low BMD comparing with low (mean $=1.190 \mathrm{~g} /$ $\mathrm{cm}^{2}$; 95\%CI: $\left.1.165 ; 1.215\right)$ and moderate $\left(\right.$ mean $=1.191 \mathrm{~g} / \mathrm{cm}^{2} ; 95 \% \mathrm{CI}: 1.171$; 1.210) categories. In addition, men always classified in the highest tertile of the "bone-unfriendly" pattern presented the lowest mean of whole body BMD (mean = 1.25g/cm²; 95\%CI: $1.243 ; 1.266)$. No associations were observed between the categories of dietary calcium intake and "bone-friendly" pattern and each of the three BMD outcomes. These results point to the fact that diets composed of inhibiting foods/nutrients can contribute negatively to bone health.
\end{abstract}

Bone Density; Dual-Energy Radiographic Absorptiometry; Milk; Calcium; Diet
Isabel Oliveira Bierhals 1

Juliana dos Santos Vaz 1

Ana Maria Baptista Menezes 1

Fernando César Wehrmeister 1

Leonardo Pozza 2

Maria Cecília Formoso Assunção 1

doi: 10.1590/0102-311X00192418

Correspondence

I. O. Bierhals

Universidade Federal de Pelotas.

Rua Marechal Deodoro 1160, 3o andar, Pelotas, RS 96020-220, Brasil.

isabelbierhals@gmail.com

1 Universidade Federal de Pelotas, Pelotas, Brasil.

2 Universidade Federal do Pampa, Bagé, Brasil. 


\section{Introduction}

Bones are considered the main reservoir of calcium in the human body and maintain 99\% of total body calcium ${ }^{1}$. Calcium is mainly stored in the form of hydroxyapatite and it provides bone stiffness and minimizes the risk of fractures 2 . During childhood and adolescence, anabolic processes predominate in the bone, which leads to an increase in size and mineral content and results in the individual's growth. Approximately $90 \%$ of peak bone mass (PBM) - the maximum amount of bone mass that an individual accumulates from birth to skeletal maturity - is obtained up to the age of 20 years. However, it may vary between individuals and the skeletal regions 3,4 .

The accumulation and maintenance of bone mineral mass, usually assessed through bone mineral content (BMC) and density (BMD), is a multifactorial process, influenced by age, sex, heredity and by potentially modifiable life behaviors 5,6,7. Genetic factors account for approximately $70 \%$ of the variance in bone mass 8 . Male subjects have higher bone mass than female, as well as black subjects, comparing with white non-Hispanic or Asian 6. Several hormones affect bone mass. Estrogen plays an important part in maintaining BMD in women. Testosterone, growth hormone, and IGF-1 all promote bone formation, whereas glucocorticoid excess both increases bone resorption and impairs bone formation 6 .

Physical activity, especially mechanical loading during weight-bearing exercise improves bone mineral accrual in children and adolescents 9 . Maintaining a healthy body weight during childhood and adolescence is also recommended to optimize bone health 6 . In addition, many of the foods and nutrients people eat as part of their daily diet may have a positive or negative impact on bone health 5,6. Diet factors supporting the development and maintenance of bone mass include calcium, vitamin D, protein, potassium, among others. Factors such as oxalic acid, phytic acid, sodium, caffeine and, particularly, the excess of those, can potentially interfere with the absorption and retention of calcium and thereby have a negative effect 5,10 .

Milk and dairy products in general are the best sources of calcium in a diet and also provide more protein, magnesium, potassium, zinc and phosphorus - all of which important for bone health as well - than any other food 11,12. However, there is still a debate on the effect of calcium dietary intake as well as milk and its derivatives on the acquisition of bone mass in the different phases of life. For example, the effect of breastfeeding is not consistent among studies 13,14,15, and few of them indicate that it exerts a protective effect on bone health 14,15 . Concerning childhood, the literature is more consistent about the protective effect of calcium from dairy products on bone mineral mass $16,17,18,19,20,21$. Two meta-analyses confirmed a beneficial impact on bone mineral accumulation at this stage of growth 22,23. As for adolescence, studies have shown that the protective effect is not so clear and does not occur equally among boys and girls 24,25,26, whereas in adulthood there is no evidence that the consumption of dietary calcium and dairy products helps to reduce the risk of osteoporosis and future bone fractures $27,28,29,30$.

In addition to examining potential relationships between dietary intake and bone quality through the individual effect of nutrients or foods 31 , analyses of dietary patterns have been used to elucidate possible associations between the combined intake of a set of foods or nutrients and bone health $31,32,33$. This type of analysis assesses the subjects' general tendencies to consume more often certain types of food and meals, rather than a single food or nutrient, thus making it possible to test the intercorrelation between them 33 .

Our study aimed to evaluate the effect of dietary calcium intake, milk consumption and dietary patterns generated from nutrients that act as facilitators ("bone-friendly") or inhibitors of calcium absorption ("bone-unfriendly") from late adolescence to early adulthood, on BMD at 22 years of age. The study used data from a birth cohort study conducted in the city of Pelotas, Rio Grande do Sul State, in Southern Brazil. 


\section{Materials and methods}

\section{Pelotas (Brazil) birth cohort study}

The 1993 Pelotas (Brazil) birth cohort study recruited all hospital births from mothers living in the urban area of Pelotas, between 1st January and 31st December 1993 34. In 1993, there were a total of 5,265 live births, and 5,249 mother-baby pairs agreed to participate. Detailed information on the cohort methodology has been reported elsewhere $34,35,36$.

The present study used data from the follow-ups at 18 and 22 years. The sample comprised individuals with information available on diet and bone mass at both follow-ups.

\section{Diet assessment}

A semi-qualitative Food Frequency Questionnaire (FFQ) 37, administered through an electronic platform, assessed dietary consumption at 18 and 22 years. The FFQ comprised 88 food items and eight frequency options were given: (i) never or fewer than once per month; (ii) one to three times per month; (iii) once per week; (iv) two to four times per week; (v) five to six times per week; (vi) once per day; (vii) two to four times per day; and (viii) five or more times per day. The participants were requested to report their intake referring to the preceding 12 months. Daily energy intake in kilocalories and nutrient intake were estimated using the Brazilian Food Composition Table 38, supplemented with food and nutrient items from other sources $39,40,41$.

\section{Milk consumption}

For the analyses, the frequencies of milk consumption obtained at both follow-ups were categorized into five consumption categories: "always high" (corresponding to the two highest categories of consumption: "two to four times per day" or "five or more times per day" at 18 and at 22 years), "always moderate" (accounting for four intermediate categories at both follow-ups: "once per week"; "two to four times per week"; "five to six times per week"; or "once per day"), "always low" (corresponding to the two lowest consumption categories: "never or fewer than once per month" or "one to three times per month" at both follow-ups), "increase" (accounting for any increase in the frequency of consumption observed at the two follow-ups) and "decrease" (for any decrease in the frequency of consumption at the two follow-ups).

We opted for the non-inclusion of dairy consumption in the analysis related to the effect of milk intake on bone mass. This decision was due to the fact that the food data collected showed that the daily intake of calcium from cheese and yogurt represented $8.6 \%$ and $14 \%$ at 18 years, respectively, and $11.1 \%$ and $5.9 \%$ at 22 years of total ingested calcium (data not shown), confirming its low consumption in the study population. On the other hand, milk was the food that contributed the most to the dietary calcium intake at 18 years of age, representing $28.2 \%$ of the daily calcium consumed and $22.5 \%$ at 22 years. However, the contribution of these foods was considered in the analysis concerning the effect of calcium consumption.

\section{Dietary calcium intake}

Data on calcium intake was determined by adding up the availability of calcium in all foods listed in the FFQ. The continuous calcium variable was categorized into tertiles to produce similar categories to those formed for milk: "always high" (corresponding to the highest tertile of consumption at 18 and at 22 years), "always moderate" (corresponding to the intermediate tertiles at both follow-ups), "always low" (corresponding to the lowest tertiles of calcium intake at the two follow-ups), "increase" (accounting for any increase in the tertiles of calcium intake observed at the two follow-ups) and "decrease" (for any decrease in tertiles of calcium at the two follow-ups). 


\section{Nutrient patterns}

Nutrient patterns were constructed from seven nutrients - phytate, oxalate, protein, calcium, vitamin $\mathrm{D}$, sodium and caffeine, as those nutrients affect calcium absorption 5,10. Principal component analysis (PCA) and rotation were applied to derive the patterns, which allowed the food groups to be combined based on the degree of intercorrelation between them. A correlation matrix was constructed to assess the correlation between the food groups. The Kaiser-Meyer-Olkin test $(\geq 0.8)$ and Bartlett's test of sphericity (p-value $<0.05$ ) were applied to verify whether the PCA assumptions would be met 42,43 . Factorial analysis without restriction was conducted on the number of factors to be retained by using a varimax orthogonal rotation in order to obtain uncorrelated patterns and improve the data interpretation. Food groups that showed factor loadings $\geq|0.4|$ were considered to have strong associations with that factor.

The number of components to be extracted was defined based on the eigenvalue criteria greater than one and on the scree plot graphic, in which the points of greatest slope indicate the number of factors to be considered in the analysis 44 . After that, the model was constructed by fixing the number of patterns to be retained in accordance with the number indicated by the graph. Nutrient patterns were named according to the nutrient's items included and their interpretation. The participants received a factor score for each nutrient pattern identified 45 .

Each pattern score was categorized into tertiles to produce the same five categories: "always high" (corresponding to the third tertile of consumption at 18 and at 22 years), "always moderate" (corresponding to the intermediate tertile at both follow-ups), "always low" (corresponding to the first tertile of nutrient patterns at the two follow-ups), "increase" (accounting for any increase in the tertiles of nutrient patterns observed at the two follow-ups) and "decrease" (for any decrease in tertiles of patterns at the two follow-ups).

\section{Bone mass assessment}

Dual-energy X-ray absorptiometry (DXA) (Lunar Prodigy Advance, GE Healthcare, USA) was used to assess areal BMD (aBMD; $\mathrm{g} / \mathrm{cm}^{2}$ ) of the lumbar spine (L1-L4), the right femur and whole body at 22 years. These variables were analyzed continuously. The participants that did not undergo the DXA tests included those who were pregnant or possibly pregnant, those who were wheelchair users or individuals with osteoarticular deformities, and those who were morbidly obese (>120kg) or taller than $192 \mathrm{~cm}$. Individuals that were over $192 \mathrm{~cm}$ tall did not undergo BMD whole body measurement, but had their lumbar spine and femur scanned.

\section{Potential confounders}

Variables considered as potential confounding factors in the association between milk consumption and bone mass, collected at the perinatal interview, were applied in the adjusted analysis, and include: family income at birth (in Brazilian Reals); maternal education (years of study); birth weight (grams); length at birth (centimeters). This adjustment also encompassed the variables collected at 15 years (self-reported skin color) and at 18 years: smoking (at least one cigarette per day during the month leading up to the interview), moderate and vigorous physical activity (using leisure-time and commuting sections from the International Physical Activity Questionnaire - IPAQ long version 46; leisure-time and commuting activities were classified as moderate and vigorous intensity as proposed by Pate et al. 47 ), total calorie intake and soft drink consumption (kcal) and finally at 22 years of age: height (centimeters).

\section{Statistical analyses}

All statistical analyses were carried out by using the statistical package Stata 12.1 (https://www.stata. com) and stratified by sex, given that the evidences suggested the existence of gender differences in bone mass at different phases of life 48,49 . A descriptive analysis was performed, and included a 
description of absolute and relative frequencies for categorical variables, and mean and standard deviation (SD) or median and interquartile range (p25-p75) for numeric variables.

In order to assess the effects of milk consumption, dietary calcium intake and nutrient patterns from 18 to 22 years of age on bone mass at 22 years, means $95 \%$ confidence intervals $(95 \% \mathrm{CI})$, adjusted $\mathrm{R}$ squared $\left(\mathrm{R}^{2}\right)$ and $\mathrm{p}$-values from the Wald test for heterogeneity were obtained by multiple linear regression, with statistical significance at $\mathrm{p}<0.05$. In the adjusted models, all the potential confounders were included in the regression, irrespective of their level of significance with the outcome on bivariate analysis. Variance inflation factor was used to assess the presence of collinearity in the tested models.

\section{Ethics statement}

All the follow-ups from the 1993 Pelotas (Brazil) birth cohort study were approved by the Ethics Research Committee of the Federal University of Pelotas Medical School under permit number 1.250.366. At all stages, the participants (or their legal guardians) signed an Informed Consent Form.

\section{Results}

\section{Study participants}

The follow-up retention rate at 18 years was $81.3 \%$ relative to the original cohort, with data collected from 4,106 participants. At 22 years, 3,810 individuals (follow-up retention rate of 76.3\%) were interviewed 35,36 . Out of the total number of participants assessed at those two moments, data on milk consumption and bone mineral mass were available for 3,109 and comprised the sample for the present study. In this group, 1,653 (53.2\%) were female. Table 1 shows the differences between the participants included in and those excluded from the current analysis. For both sexes, there were differences regarding birth weight and smoking at 18 years. Among males, a higher percentage of excluded individuals came from families with an income at birth $\leq 1$ monthly minimum wage (MMW) and those taller at 22 years. Among women, a higher percentage of included participants had mothers with 5 to 11 years of schooling when compared with those women excluded from the current analysis and regarding to gestational age, the percentage of those born at 37-40 weeks was greater among excluded women.

\section{Bone mass at 22 years of age}

Table 1 also shows the mean of the outcomes at 22 years of age among participants included and excluded from the current analysis. Only the whole body BMD for males was slightly higher among those included as compared to those excluded ( $\left.1.3 \mathrm{vs} .1 .2 \mathrm{~g} / \mathrm{cm}^{2} ; \mathrm{p}=0.033\right)$. The whole body BMD mean among the included women was $1.2 \mathrm{~g} / \mathrm{cm}^{2}$. For lumbar spine BMD, the mean was $1.2 \mathrm{~g} / \mathrm{cm}^{2}$ among men and women, while for right femur BMD, it was 1.2 for men and $1.0 \mathrm{~g} / \mathrm{cm}^{2}$ for women.

\section{Milk consumption and bone mass}

Table 2 shows the adjusted analyses and $\mathrm{R}^{2}$ of the associations between milk consumption and BMD. In right femur site $\left(\mathrm{R}^{2}=8.44\right)$, men classified into the "always high" (mean $=1.148 \mathrm{~g} / \mathrm{cm}^{2} ; 95 \% \mathrm{CI}$ : $1.116 ; 1.181$ ) and "increased" categories of milk consumption (mean $=1.154 \mathrm{~g} / \mathrm{cm}^{2} ; 95 \%$ CI: 1.135 ; 1.174) presented a slightly low BMD comparing with low (mean $\left.=1.190 \mathrm{~g} / \mathrm{cm}^{2} ; 95 \% \mathrm{CI}: 1.165 ; 1.215\right)$ and moderate $\left(\right.$ mean $\left.=1.191 \mathrm{~g} / \mathrm{cm}^{2} ; 95 \% \mathrm{CI}: 1.171 ; 1.210\right)$ categories $(\mathrm{p}=0.024)$. No associations were observed for women's right femur BMD neither for whole body nor lumbar spine BMD and milk consumption in both sexes. 
Table 1

Characteristics of participants with complete data at both 18th and 22nd-year follow-ups compared with those participants with missing data, loss of follow-up or death, stratified by sex. 1993 Pelotas (Brazil) birth cohort.

\begin{tabular}{|c|c|c|c|c|c|c|}
\hline \multirow[t]{4}{*}{ Variables } & \multicolumn{3}{|c|}{ Men } & \multicolumn{3}{|c|}{ Women } \\
\hline & \multicolumn{2}{|c|}{ Mean or median (SD or p25-p75); \% } & \multirow[t]{3}{*}{ p-value } & \multicolumn{2}{|c|}{ Mean or median (SD or p25-p75); \% } & \multirow[t]{3}{*}{ p-value } \\
\hline & Participants & Participants & & Participants & Participants & \\
\hline & included $(n=1,456)$ & excluded * $(n=1,147)$ & & included $(n=1,653)$ & excluded * $(n=992)$ & \\
\hline \multicolumn{7}{|l|}{ Perinatal } \\
\hline Maternal education (years) & $\mathrm{n}=1,454$ & $\mathrm{n}=1,145$ & $0.151 * *$ & $\mathrm{n}=1,650$ & $\mathrm{n}=992$ & $0.011 * *$ \\
\hline $0-4$ & 25.4 & 29.3 & & 27.0 & 32.1 & \\
\hline $5-8$ & 47.5 & 45.5 & & 47.0 & 44.2 & \\
\hline $9-11$ & 18.4 & 17.6 & & 18.3 & 15.1 & \\
\hline$\geq 12$ & 8.7 & 7.6 & & 7.7 & 8.7 & \\
\hline Family income (MMW) & $n=1,435$ & $n=1,112$ & $0.011 * \star$ & $n=1,619$ & $\mathrm{n}=970$ & $0.329 * *$ \\
\hline$\leq 1$ & 17.6 & 21.0 & & 17.4 & 20.3 & \\
\hline $1.1-3$ & 42.3 & 42.4 & & 41.8 & 40.6 & \\
\hline $3.1-6$ & 24.7 & 19.8 & & 24.8 & 23.5 & \\
\hline$>6$ & 15.4 & 16.8 & & 16.0 & 15.6 & \\
\hline Gestational age (weeks) & $n=1,438$ & $\mathrm{n}=1,112$ & $0.245 * *$ & $\mathrm{n}=1,631$ & $\mathrm{n}=958$ & $0.001 * *$ \\
\hline$<34$ & 1.1 & 2.1 & & 1.2 & 3.0 & \\
\hline $34-36$ & 6.2 & 6.4 & & 7.9 & 6.5 & \\
\hline $37-40$ & 76.1 & 75.9 & & 77.3 & 79.3 & \\
\hline$>40$ & 16.6 & 15.6 & & 13.6 & 11.2 & \\
\hline Weight (grams) & $\mathrm{n}=1,455$ & $n=1,140$ & $0.010 * \star$ & $n=1,652$ & $\mathrm{n}=985$ & $0.001 * *$ \\
\hline$<2,500$ & 7.5 & 10.3 & & 11.0 & 10.5 & \\
\hline 2,500-2,999 & 22.7 & 18.8 & & 26.4 & 33.6 & \\
\hline 3,000-3,999 & 63.6 & 63.7 & & 59.0 & 53.4 & \\
\hline$\geq 4,000$ & 6.2 & 7.2 & & 3.6 & 2.5 & \\
\hline \multirow[t]{2}{*}{ Length (cm) } & $\mathrm{n}=1,443$ & $n=1,117$ & $0.887 * \star \star$ & $n=1,640$ & $n=962$ & $0.069 * * *$ \\
\hline & $49.1(2.3)$ & $49.1(2.6)$ & & $48.5(2.3)$ & $48.3(2.3)$ & \\
\hline \multicolumn{7}{|l|}{15 years } \\
\hline Skin color & $n=1,387$ & $n=723$ & $0.363 * *$ & $\mathrm{n}=1,630$ & $n=583$ & $0.175 * *$ \\
\hline White & 63.6 & 65.7 & & 62.9 & 66.2 & \\
\hline Black, brown or other & 36.4 & 34.3 & & 37.1 & 33.8 & \\
\hline \multicolumn{7}{|l|}{18 years } \\
\hline Smoking habit & $n=1,455$ & $\mathrm{n}=559$ & $0.038 * *$ & $n=1,653$ & $n=438$ & $0.007 * *$ \\
\hline No & 85.8 & 81.9 & & 88.0 & 82.9 & \\
\hline Yes & 14.2 & 18.1 & & 12.0 & 17.1 & \\
\hline Moderate and vigorous & $n=1,410$ & $n=539$ & $0.610 \#$ & $n=1,640$ & $n=434$ & $0.418 \#$ \\
\hline \multirow[t]{2}{*}{ physical activity (min/week) } & 477.5 & 440.0 & & 240.0 & 290.0 & \\
\hline & $(240.0 ; 810.0)$ & $(240.0 ; 840.0)$ & & $(107.5 ; 497.5)$ & $(120.0 ; 525.0)$ & \\
\hline \multirow[t]{3}{*}{ Total calorie intake (kcal) } & $\mathrm{n}=1,456$ & $n=537$ & $0.089 \#$ & $n=1,653$ & $n=423$ & $0.277 \#$ \\
\hline & $2,759.7$ & $2,656.6$ & & $2,370.1$ & $2,491.1$ & \\
\hline & $(1,948.1 ; 4,203.0)$ & $(1,825.6 ; 4,082.8)$ & & $(1,630.9 ; 3,696.1)$ & $(1,709.9 ; 4,071.4)$ & \\
\hline Soft drink consumption & $\mathrm{n}=1,453$ & $\mathrm{n}=537$ & $0.661 \#$ & $n=1,648$ & $n=421$ & $0.630 \#$ \\
\hline \multirow{2}{*}{ (kcal) } & 35.7 & 35.7 & & 35.7 & 35.7 & \\
\hline & $(17.8 ; 125.3)$ & $(17.8 ; 125.3)$ & & $(11.9 ; 89.2)$ & $(11.9 ; 125.3)$ & \\
\hline \multicolumn{7}{|l|}{22 years } \\
\hline \multirow[t]{2}{*}{ Height (cm) } & $n=1,456$ & $n=247$ & $<0.001 * * *$ & $n=1,653$ & $n=236$ & $0.087 * * *$ \\
\hline & $174.0(6.7)$ & $176.7(9.0)$ & & $161.2(6.5)$ & $160.4(7.0)$ & \\
\hline \multirow[t]{2}{*}{ Whole body BMD $\left(\mathrm{g} / \mathrm{cm}^{2}\right)$} & $\mathrm{n}=1,456$ & $\mathrm{n}=91$ & $0.033 * \star \star$ & $\mathrm{n}=1,653$ & $\mathrm{n}=128$ & $0.603 * * *$ \\
\hline & $1.3(0.1)$ & $1.2(0.1)$ & & $1.2(0.1)$ & $1.2(0.1)$ & \\
\hline \multirow[t]{2}{*}{ Lumbar spine BMD (g/cm²) } & $\mathrm{n}=1,452$ & $\mathrm{n}=120$ & $0.993 * \star \star$ & $\mathrm{n}=1,649$ & $n=131$ & $0.759 * * *$ \\
\hline & $1.2(0.1)$ & $1.2(0.2)$ & & $1.2(0.1)$ & $1.2(0.1)$ & \\
\hline \multirow[t]{2}{*}{ Right femur BMD (g/cm²) } & $n=1,455$ & $\mathrm{n}=117$ & $0.510 * \star \star$ & $\mathrm{n}=1,651$ & $n=129$ & $0.745 * \star *$ \\
\hline & $1.2(0.2)$ & $1.2(0.2)$ & & $1.0(0.1)$ & $1.0(0.1)$ & \\
\hline
\end{tabular}

p25-p75: interquartile range; BMD: bone mineral density; MMW: monthly minimum wages; SD: standard deviation.

* Participants excluded from the analyses due to loss of follow-up or missing data;

** p-value refers to Chi-squared heterogeneity test;

*** p-value refers to Student's t-test;

\# p-value refers to Wilcoxon Rank Sum test. 


\section{Table 2}

Adjusted analyses and adjusted R-squared $\left(\mathrm{R}^{2}\right)$ of the association between milk consumption from 18 to 22 years and bone mineral density (BMD: g/cm²) at 22 years of age. 1993 Pelotas (Brazil) birth cohort.

\begin{tabular}{|c|c|c|c|c|c|c|}
\hline \multirow[t]{4}{*}{ Variable } & \multicolumn{6}{|c|}{ Men } \\
\hline & \multicolumn{2}{|c|}{ Whole body BMD } & \multicolumn{2}{|c|}{ Lumbar spine BMD } & \multicolumn{2}{|c|}{ Right femur BMD } \\
\hline & Mean * $(95 \% \mathrm{CI})$ & p-value & Mean * $(95 \% \mathrm{Cl})$ & p-value & Mean * $(95 \% \mathrm{Cl})$ & p-value \\
\hline & {$[n=1,308]$} & & {$[n=1,304]$} & & {$[n=1,307]$} & \\
\hline Milk consumption & $R^{2}=11.74$ & 0.215 & $\mathrm{R}^{2}=6.93$ & 0.078 & $\mathrm{R}^{2}=8.44$ & 0.024 \\
\hline Low & $1.273(1.259 ; 1.287)$ & & $1.255(1.234 ; 1.276)$ & & $1.190(1.165 ; 1.215)$ & \\
\hline Moderate & $1.273(1.261 ; 1.284)$ & & $1.240(1.223 ; 1.257)$ & & $1.191(1.171 ; 1.210)$ & \\
\hline High & $1.259(1.241 ; 1.278)$ & & $1.212(1.184 ; 1.240)$ & & $1.148(1.116 ; 1.181)$ & \\
\hline Increase & $1.263(1.252 ; 1.274)$ & & $1.225(1.208 ; 1.241)$ & & $1.154(1.135 ; 1.174)$ & \\
\hline Decrease & $1.277(1.269 ; 1.285)$ & & $1.241(1.229 ; 1.253)$ & & $1.181(1.167 ; 1.194)$ & \\
\hline \multirow[t]{4}{*}{ Variable } & \multicolumn{6}{|c|}{ Women } \\
\hline & \multicolumn{2}{|c|}{ Whole body BMD } & \multicolumn{2}{|c|}{ Lumbar spine BMD } & \multicolumn{2}{|c|}{ Right femur BMD } \\
\hline & Mean * $(95 \% \mathrm{Cl})$ & p-value & Mean * $(95 \% \mathrm{Cl})$ & p-value & Mean * $(95 \% \mathrm{Cl})$ & p-value \\
\hline & {$[n=1,544]$} & & {$[n=1,540]$} & & {$[n=1,542]$} & \\
\hline Milk consumption & $R^{2}=6.76$ & 0.686 & $R^{2}=4.87$ & 0.737 & $R^{2}=6.62$ & 0.134 \\
\hline Low & $1.160(1.151 ; 1.169)$ & & $1.206(1.192 ; 1.221)$ & & $1.026(1.021 ; 1.051)$ & \\
\hline Moderate & $1.162(1.153 ; 1.171)$ & & $1.207(1.193 ; 1.222)$ & & $1.041(1.026 ; 1.056)$ & \\
\hline High & $1.148(1.132 ; 1.165)$ & & $1.191(1.163 ; 1.218)$ & & $1.013(0.985 ; 1.041)$ & \\
\hline Increase & 1.159 (1.150; 1.167) & & $1.200(1.187 ; 1.214)$ & & $1.034(1.020 ; 1.048)$ & \\
\hline Decrease & $1.159(1.152 ; 1.165)$ & & $1.198(1.188 ; 1.209)$ & & $1.021(1.010 ; 1.032)$ & \\
\hline
\end{tabular}

95\%Cl: 95\% confidence interval.

Notes: p-value refers to Wald's test for heterogeneity. Low: categories "never or less than once per month" or "one to three times per month" at both follow-ups; Moderate: categories "once per week", "two to four times per week", "five to six times per week" or "once per day" at both follow-ups; High: categories "two to four times per day" or "five or more times per day" at both follow-ups; Increase: category representing any increase in frequency of consumption observed at the two follow-ups; Decrease: for any decrease in frequency of consumption at the two follow-ups.

* Adjusted for variables collected during the perinatal period (family income, maternal education, gestational age, birth weight, length at birth), at 15 years (skin color), 18 years (smoking habit, moderate and vigorous physical activity, soft drink consumption, total calorie intake) and 22 years of age (height).

\section{Dietary calcium intake and bone mass}

Table 3 shows the adjusted analyses and $\mathrm{R}^{2}$ of the association between calcium dietary intake and BMD at 22 years of age. No associations were observed between the categories of dietary calcium intake and each of the three BMD outcomes (whole body, lumbar spine and right femur) in both sexes.

\section{Nutrient patterns and bone mass}

Two nutrient patterns were identified, which explained $81.8 \%$ of the total data variability. The KMO value was 0.82 , and the Bartlett test was $<0.001$ at both ages, which indicated good factorial adjustment. The patterns were named based on the characteristics of the items held in each pattern (bonefriendly pattern and bone-unfriendly pattern). The so-called "bone-friendly" pattern was characterized by the consumption of oxalate, protein, calcium and sodium. The "bone-unfriendly" pattern was characterized by the consumption of caffeine and a negative loading on vitamin D (Supplementary Material. Table S1: http://cadernos.ensp.fiocruz.br/site/public_site/arquivo/supl-e00192418_ 3924.pdf).

In both men and women, the "bone-friendly" pattern was not associated to any of the three BMD outcomes (whole body, lumbar spine and right femur) (Table 4). On the other hand, men always 


\section{Table 3}

Adjusted analyses and adjusted R-squared $\left(R^{2}\right)$ of the association between dietary calcium intake from 18 to 22 years and bone mineral density (BMD: $\mathrm{g} / \mathrm{cm}^{2}$ ) at 22 years of age. 1993 Pelotas (Brazil) birth cohort.

\begin{tabular}{|c|c|c|c|c|c|c|}
\hline \multirow[t]{4}{*}{ Variable } & \multicolumn{6}{|c|}{ Men } \\
\hline & \multicolumn{2}{|c|}{ Whole body BMD } & \multicolumn{2}{|c|}{ Lumbar spine BMD } & \multicolumn{2}{|c|}{ Right femur BMD } \\
\hline & Mean * $(95 \% \mathrm{Cl})$ & p-value & Mean * $(95 \% \mathrm{Cl})$ & p-value & Mean * $(95 \% \mathrm{CI})$ & p-value \\
\hline & {$[n=1,308]$} & & {$[n=1,304]$} & & {$[n=1,307]$} & \\
\hline Calcium intake & $R^{2}=11.62$ & 0.435 & $\mathrm{R}^{2}=6.67$ & 0.310 & $\mathrm{R}^{2}=7.78$ & 0.721 \\
\hline Low & $1.272(1.260 ; 1.283)$ & & $1.241(1.223 ; 1.259)$ & & $1.171(1.150 ; 1.192)$ & \\
\hline Moderate & $1.272(1.258 ; 1.286)$ & & $1.242(1.221 ; 1.263)$ & & $1.185(1.160 ; 1.209)$ & \\
\hline High & $1.271(1.258 ; 1.284)$ & & $1.236(1.217 ; 1.256)$ & & $1.188(1.166 ; 1.211)$ & \\
\hline Increase & $1.278(1.269 ; 1.287)$ & & $1.245(1.231 ; 1.259)$ & & $1.173(1.156 ; 1.189)$ & \\
\hline Decrease & $1.264(1.253 ; 1.274)$ & & $1.222(1.207 ; 1.238)$ & & $1.172(1.153 ; 1.191)$ & \\
\hline \multirow[t]{4}{*}{ Variable } & \multicolumn{6}{|c|}{ Women } \\
\hline & \multicolumn{2}{|c|}{ Whole body BMD } & \multicolumn{2}{|c|}{ Lumbar spine BMD } & \multicolumn{2}{|c|}{ Right femur BMD } \\
\hline & Mean * $(95 \% \mathrm{Cl})$ & p-value & Mean * $(95 \% \mathrm{CI})$ & p-value & Mean * $(95 \% \mathrm{Cl})$ & p-value \\
\hline & {$[n=1,544]$} & & {$[n=1,540]$} & & {$[n=1,542]$} & \\
\hline Calcium intake & $\mathrm{R}^{2}=6.70$ & 0.878 & $\mathrm{R}^{2}=4.81$ & 0.904 & $\mathrm{R}^{2}=6.29$ & 0.812 \\
\hline Low & $1.158(1.148 ; 1.169)$ & & $1.202(1.185 ; 1.219)$ & & $1.034(1.016 ; 1.051)$ & \\
\hline Moderate & $1.163(1.153 ; 1.173)$ & & $1.209(1.192 ; 1.225)$ & & $1.038(1.021 ; 1.055)$ & \\
\hline High & $1.159(1.151 ; 1.168)$ & & $1.201(1.186 ; 1.215)$ & & $1.029(1.014 ; 1.044)$ & \\
\hline Increase & $1.159(1.151 ; 1.167)$ & & $1.202(1.188 ; 1.215)$ & & $1.026(1.012 ; 1.039)$ & \\
\hline Decrease & $1.156(1.149 ; 1.164)$ & & $1.198(1.185 ; 1.210)$ & & $1.027(1.014 ; 1.040)$ & \\
\hline
\end{tabular}

95\% Cl: 95\% confidence interval.

Notes: p-value refers to Wald's test for heterogeneity; Low: categories "never or less than once per month" or "one to three times per month" at both follow-ups; Moderate: categories "once per week", "two to four times per week", "five to six times per week", or "once per day" at both follow-ups; High: categories "two to four times per day" or "five or more times per day" at both follow-ups; Increase: category representing any increase in frequency of consumption observed at the two follow-ups; Decrease: for any decrease in frequency of consumption at the two follow-ups.

* Adjusted for variables collected during the perinatal period (family income, maternal education, gestational age, birth weight, length at birth), at 15 years (skin color), 18 years (smoking habit, moderate and vigorous physical activity, soft drink consumption, total calorie intake) and 22 years of age (height).

classified in the highest tertile of the "bone-unfriendly" pattern presented the lowest mean of whole body BMD $\left(\right.$ mean $\left.=1.254 \mathrm{~g} / \mathrm{cm}^{2} ; 95 \% \mathrm{CI}: 1.243 ; 1.266 ; \mathrm{R}^{2}=12.20\right)(\mathrm{p}=0.015)($ Table 5$)$.

\section{Discussion}

The present study aimed to investigate the role of milk consumption, dietary calcium and nutrient patterns ("bone-friendly" and "bone-unfriendly"), from late adolescence to early adulthood, on BMD at 22 years of age. Associations were observed for milk consumption and "bone-unfriendly" pattern with slight differences in whole body and right femur BMD only among men.

One aspect that may support the lack of association is the low calcium intake in the population studied. At the age of 18, only 25\% of the respondents met the daily Estimated Average Requirements (EAR) of the mineral (1,100mg per day) and, at the age of $22,42 \%$ (800mg per day) 39 . Other aspects that may be influencing the absence of associations are the small differences in BMD between the exposure groups.

Most of the evidence reported in the scientific literature regarding the effect of dietary calcium intake on BMD derives from randomized clinical trials conducted by drug supplementation 29,30,50. 


\section{Table 4}

Adjusted analyses and adjusted R-squared $\left(R^{2}\right)$ of the association between bone-friendly nutrient pattern from 18 to 22 years and bone mineral density (BMD: $\mathrm{g} / \mathrm{cm}^{2}$ ) at 22 years of age. 1993 Pelotas (Brazil) birth cohort, Brazil.

\begin{tabular}{|c|c|c|c|c|c|c|}
\hline \multirow[t]{4}{*}{ Variable } & \multicolumn{6}{|c|}{ Men } \\
\hline & \multicolumn{2}{|c|}{ Whole body BMD } & \multicolumn{2}{|c|}{ Lumbar spine BMD } & \multicolumn{2}{|c|}{ Right femur BMD } \\
\hline & Mean * $(95 \% \mathrm{Cl})$ & p-value & Mean * $(95 \% \mathrm{Cl})$ & p-value & Mean * $(95 \% \mathrm{Cl})$ & p-value \\
\hline & {$[n=1,308)$} & & {$[n=1,304]$} & & {$[n=1,307]$} & \\
\hline Bone-friendly & $R^{2}=11.92$ & 0.079 & $R^{2}=6.63$ & 0.377 & $\mathrm{R}^{2}=8.31$ & 0.052 \\
\hline Low & $1.281(1.267 ; 1.295)$ & & $1.251(1.229 ; 1.272)$ & & $1.191(1.167 ; 1.216)$ & \\
\hline Moderate & 1.285 (1.272; 1.299) & & $1.246(1.226 ; 1.266)$ & & $1.204(1.181 ; 1.228)$ & \\
\hline High & $1.263(1.251 ; 1.274)$ & & $1.231(1.214 ; 1.249)$ & & $1.158(1.138 ; 1.179)$ & \\
\hline Increase & $1.266(1.256 ; 1.277)$ & & $1.228(1.212 ; 1.244)$ & & $1.172(1.153 ; 1.191)$ & \\
\hline Decrease & $1.271(1.262 ; 1.281)$ & & $1.239(1.225 ; 1.254)$ & & $1.173(1.156 ; 1.190)$ & \\
\hline \multirow[t]{4}{*}{ Variable } & \multicolumn{6}{|c|}{ Women } \\
\hline & \multicolumn{2}{|c|}{ Whole body BMD } & \multicolumn{2}{|c|}{ Lumbar spine BMD } & \multicolumn{2}{|c|}{ Right femur BMD } \\
\hline & Mean * $(95 \% \mathrm{Cl})$ & p-value & Mean * $(95 \% \mathrm{Cl})$ & p-value & Mean * $(95 \% \mathrm{CI})$ & p-value \\
\hline & {$[n=1,544]$} & & {$[n=1,540]$} & & {$[n=1,542]$} & \\
\hline Bone-friendly & $\mathrm{R}^{2}=6.80$ & 0.590 & $\mathrm{R}^{2}=4.91$ & 0.644 & $\mathrm{R}^{2}=6.33$ & 0.687 \\
\hline Low & $1.162(1.154 ; 1.171)$ & & $1.201(1.187 ; 1.215)$ & & $1.032(1.018 ; 1.046)$ & \\
\hline Moderate & 1.161 (1.150; 1.172) & & $1.213(1.195 ; 1.231)$ & & $1.040(1.021 ; 1.059)$ & \\
\hline High & $1.150(1.138 ; 1.161)$ & & $1.192(1.173 ; 1.211)$ & & $1.023(1.003 ; 1.043)$ & \\
\hline Increase & $1.161(1.153 ; 1.168)$ & & $1.203(1.190 ; 1.215)$ & & $1.032(1.019 ; 1.045)$ & \\
\hline Decrease & $1.159(1.151 ; 1.167)$ & & $1.201(1.188 ; 1.214)$ & & $1.024(1.011 ; 1.038)$ & \\
\hline
\end{tabular}

95\% Cl: 95\% confidence interval.

Notes: p-value refers to Wald's test for heterogeneity; Low: corresponding to the lowest tertiles of calcium intake at both follow-ups; Moderate: corresponding to the intermediate tertiles at both follow-ups; High: corresponding to the first tertile of consumption at both follow-ups; Increase: any increase in the tertiles of nutrient patterns at the two follow-ups; Decrease: any decrease in tertiles of patterns at the two follow-ups.

* Adjusted for variables collected during the perinatal period (family income, maternal education, gestational age, birth weight, length at birth), at 15 years (skin color), 18 years (smoking habit, moderate and vigorous physical activity, soft drink consumption, total calorie intake) and 22 years of age (height).

This is certainly due to the fact that studies involving food interventions are difficult to perform within the time required and have high costs 51 . Thus, evaluations of the effect of dietary calcium on bone come from observational studies $24,52,53,54,55$, which are more complex, especially in the measurement of food consumption. Results of such studies are still inconsistent about the beneficial effects among the different age groups, retaining doubts. In our study, only 105 subjects ( $3.38 \%$ of the total sample) reported the use of dietary supplements, such as multivitamins, which may contain calcium and/or vitamin D. We repeated the analyses, firstly with and then without these individuals, and we did not observe changes in the magnitude or direction of the associations.

Dietary guidelines indicate the consumption of milk and dairy products as the best sources of calcium and, consequently, as beneficial for bone health 56,57,58. The present study observed that those men with higher milk consumption presented a slightly lower BMD. However, this finding must be interpreted with caution. Two meta-analyses evaluated milk intake and its effect on bone mass in adults 27,28 and did not find any effect. Also, a recent Mendelian randomization evaluated the effect of milk consumption on bone mass, specifically on BMD, on a genetic variant related to the persistence of lactase (rs4988235), and found no association either 59.

Another approach used in the present study was to identify food patterns that were characterized by nutrients that act as facilitators or inhibitors of calcium absorption, which if hypothesized it would lead to a positive or negative effect on bone health. In contrast to the patterns obtained from foods, the 


\section{Table 5}

Adjusted analyses and adjusted R-squared $\left(R^{2}\right)$ for the association between bone-unfriendly nutrient pattern from 18 to 22 years and bone mineral density (BMD: $\mathrm{g} / \mathrm{cm}^{2}$ ) at 22 years of age. 1993 Pelotas (Brazil) birth cohort.

\begin{tabular}{|c|c|c|c|c|c|c|}
\hline \multirow[t]{4}{*}{ Variable } & \multicolumn{6}{|c|}{ Men } \\
\hline & \multicolumn{2}{|c|}{ Whole body BMD } & \multicolumn{2}{|c|}{ Lumbar spine BMD } & \multicolumn{2}{|c|}{ Right femur BMD } \\
\hline & Mean * $(95 \% \mathrm{Cl})$ & p-value & Mean * $(95 \% \mathrm{Cl})$ & p-value & Mean * $(95 \% \mathrm{Cl})$ & p-value \\
\hline & {$[n=1,308]$} & & {$[n=1,304]$} & & {$[n=1,307]$} & \\
\hline Bone-unfriendly & $R^{2}=12.20$ & 0.015 & $R^{2}=6.58$ & 0.459 & $\mathrm{R}^{2}=8.40$ & 0.059 \\
\hline Low & $1.282(1.268 ; 1.296)$ & & $1.241(1.221 ; 1.262)$ & & $1.177(1.152 ; 1.201)$ & \\
\hline Moderate & $1.280(1.267 ; 1.293)$ & & $1.244(1.224 ; 1.264)$ & & $1.198(1.175 ; 1.221)$ & \\
\hline High & $1.254(1.243 ; 1.266)$ & & $1.223(1.206 ; 1.240)$ & & $1.156(1.136 ; 1.175)$ & \\
\hline Increase & $1.273(1.263 ; 1.282)$ & & $1.239(1.225 ; 1.254)$ & & $1.168(1.151 ; 1.185)$ & \\
\hline Decrease & $1.273(1.263 ; 1.283)$ & & $1.241(1.225 ; 1.256)$ & & $1.189(1.171 ; 1.207)$ & \\
\hline \multirow[t]{4}{*}{ Variable } & \multicolumn{6}{|c|}{ Women } \\
\hline & \multicolumn{2}{|c|}{ Whole body BMD } & \multicolumn{2}{|c|}{ Lumbar spine BMD } & \multicolumn{2}{|c|}{ Right femur BMD } \\
\hline & Mean * $(95 \% \mathrm{Cl})$ & p-value & Mean * $(95 \% \mathrm{Cl})$ & p-value & Mean * $(95 \% \mathrm{Cl})$ & p-value \\
\hline & {$[n=1,544]$} & & {$[n=1,540]$} & & {$[n=1,542]$} & \\
\hline Bone-unfriendly & $R^{2}=6.93$ & 0.289 & $\mathrm{R}^{2}=4.85$ & 0.812 & $R^{2}=6.36$ & 0.600 \\
\hline Low & $1.164(1.155 ; 1.172)$ & & $1.198(1.184 ; 1.212)$ & & $1.032(1.017 ; 1.046)$ & \\
\hline Moderate & $1.163(1.153 ; 1.173)$ & & $1.204(1.187 ; 1.220)$ & & $1.031(1.013 ; 1.048)$ & \\
\hline High & $1.149(1.139 ; 1.160)$ & & $1.194(1.177 ; 1.211)$ & & $1.016(0.999 ; 1.034)$ & \\
\hline Increase & $1.160(1.152 ; 1.168)$ & & $1.206(1.193 ; 1.219)$ & & $1.033(1.020 ; 1.046)$ & \\
\hline Decrease & 1.158 (1.150; 1.165) & & $1.203(1.191 ; 1.216)$ & & $1.032(1.020 ; 1.045)$ & \\
\hline
\end{tabular}

95\%Cl: 95\% confidence interval.

Notes: p-value refers to Wald's test for heterogeneity; Low: corresponding to the first tertile of nutrient patterns at the two follow-ups; Moderate: corresponding to the intermediate tertile at both follow-ups; High: corresponding to the third tertile of consumption at both follow-ups; Increase: any increase in the tertiles of nutrient patterns at the two follow-ups; Decrease: any decrease in tertiles of patterns at the two follow-ups; * Adjusted for variables collected during the perinatal period (family income, maternal education, gestational age, birth weight, length at birth), at 15 years (skin color), 18 years (smoking habit, moderate and vigorous physical activity, soft drink consumption, total calorie intake) and 22 years of age (height).

patterns obtained from nutrients can characterize specific nutritional profiles allowing comparisons in the populations. This approach is particularly useful for identifying nutrient combinations that may reflect possible biological mechanisms 60 . By expressing the combined and potentially synergistic effects of the various foods/nutrients consumed in the usual diet of a given population, the World Health Organization recommends that the assessment of dietary intake in population studies to be based on dietary patterns 61 .

For the "bone-friendly" pattern, associations were not found. For the bone-unfriendly pattern, we observed that men who were classified into the highest score in this pattern, e.g. high in caffeine and a negative loading on vitamin D, presented a lower BMD in comparison with the other categories. Studies with conventional approaches on dietary patterns have identified that adherence to "healthy" dietary patterns characterized by the consumption of fish, olive oil, fruit and vegetables and low consumption of red meat and sweets have been positively associated with BMD and risk reduction of fractures in different populations $62,63,64,65,66,67$. On the other hand, the so-called Western patterns, rich in fats and oils, meats and processed meats, are negatively associated 63 .

It is important to mention that the method of deriving nutrient patterns in this study, referred to an "a posteriori approach", through statistical components reduction and/or aggregation methods, provides specific patterns for the study population and may not be reflected in others. However, this method has the advantage of reflecting the real behavior of a population group, providing useful information for the creation of nutritional guidelines 68 . 
The strengths of the present study include: the BMD measurements obtained by DXA, a method considered gold standard for assessing bone mass; high rate of follow-up; possibility of evaluating the association between dietary intake at different ages and BMD adjusted for potential confounders, such as maternal characteristics collected at birth; and prospective analysis of the exposure.

The main limitation of this study is the retrospective methodology of estimating food consumption, related to the potential memory bias, which may interfere with the usual dietary estimation and the possibility of underestimating or overestimating the consumption 69,70 . Nevertheless, the acquisition of dietary data was performed under the supervision of a team previously trained to clarify doubts in the digital platform. This led to quick data entry, which facilitated the consistency of the analyses, eliminated the need for double data entry, and shortened the time needed for data collection 37. Another limitation is the fact that we did not have the measure of serum vitamin D, which is essential for the intestinal absorption of calcium, through the active transport of this nutrient from the lumen of the duodenum to the blood, thus guaranteeing its availability in the body 71 . Yet, the absence of adjustment for sexual maturation also needs to be reported, as well as the impact of physical activity variables, which may interfere with bone mass. However, at their 18th year most of the adolescents were expected to have completed sexual maturation, as menarche age is 12.34 years (95\%CI: $12.24 ; 12.42$ ) (data not shown), and, in boys, studies show that the voice breaking age is at 13 years and Tanner Genital Stage 5 between 14 and 15 years of age 72,73 . About physical activity, the use of IPAQ (valid for epidemiological studies ${ }^{46}$ ) may have minimized this limitation.

\section{Conclusions}

In conclusion, despite the low milk consumption and dietary calcium in our population, which could have prevented us from finding a positive effect of calcium on BMD, our results did not show the lower consumers at a higher risk for low bone density. As for the dietary patterns, which make it possible to evaluate individuals' nutrition more comprehensively, we observed that diets composed of inhibiting foods/nutrients can contribute negatively to bone health. Further studies are necessary to elucidate this relationship. 


\section{Contributors}

I. O. Bierhals designed research, performed statistical analyses, wrote the paper and had primary responsibility for final content. J. S. Vaz and M. C. F. Assunção designed research, wrote the paper, reviewed all the manuscript drafts, contributed with suggestions for the work and had primary responsibility for final content. A. M. B. Menezes and F. C. Wehrmeiste reviewed all the manuscript drafts and contributed with suggestions to the work. L. Pozza contributed in the data analysis and interpretation, reviewed the manuscript and approved the version to be submitted to the journal.

\section{Additional informations}

ORCID: Isabel Oliveira Bierhals (0000-0002-87398669); Juliana dos Santos Vaz (0000-0002-2880767X); Ana Maria Baptista Menezes (0000-00022996-9427); Fernando César Wehrmeister (00000001-7137-1747); Leonardo Pozza (0000-00023993-3786); Maria Cecília Formoso Assunção (0000-0002-7767-8835).

\section{References}

1. Ward K. Musculoskeletal phenotype through the life course: the role of nutrition. Proc Nutr Soc 2012; 71:27-37.

2. Aloia J, Bojadzievski T, Yusupov E, Shahzad G, Pollack S, Mikhail M, et al. The relative influence of calcium intake and vitamin D status on serum parathyroid hormone and bone turnover biomarkers in a double-blind, placebocontrolled parallel group, longitudinal factorial design. J Clin Endocrinol Metab 2010; 96:3216-24.

3. Bachrach LK. Acquisition of optimal bone mass in childhood and adolescence. Trends Endocrinol Metab 2001; 12:22-8.

4. Mora S, Gilsanz V. Establishment of peak bone mass. Endocrinol Metab Clin North Am 2003; 32:39-63.

5. Cashman KD. Diet, nutrition, and bone health J Nutr 2007; 137 Suppl 11:2507S-12S.

6. Golden NH, Abrams SA. Optimizing bone health in children and adolescents. Pediatrics 2014; 134:e1229-43.

7. Rizzoli R. Nutrition: its role in bone health. Best Pract Res Clin Endocrinol Metab 2008; 22:813-29.

8. Heaney RP, Abrams S, Dawson-Hughes B, Looker A, Marcus R, Matkovic V, et al. Peak bone mass. Osteoporos Int 2000; 11:985-1009.

9. Hind K, Burrows M. Weight-bearing exercise and bone mineral accrual in children and adolescents: a review of controlled trials. Bone 2007; 40:14-27.

10. Mangels AR. Bone nutrients for vegetarians. Am J Clin Nutr 2014; 100 Suppl 1:469S-75S.

\section{Acknowledgments}

This article is based on 1993 Pelotas (Brazil) birth cohort study conducted by the Postgraduate Program in Epidemiology at Federal University of Pelotas with the collaboration of the Brazilian Public Health Association (ABRASCO). From 2004 to the last follow-up, Welcome Trust supported the 1993 birth cohort study. European Union, National Support Program for Centers of Excellence (PRONEX), Brazilian National Research Council (CNPq), and Brazilian Ministry of Health supported previous phases of this study. The 22-year follow-up was supported by the Science and Technology Department, Brazilian Ministry of Health, with resources transferred through the CNPq (grant 400943/20131). This study was also financed in part by Graduate Studies Coordinating Board (Capes - finance code 001).

11. Caroli A, Poli A, Ricotta D, Banfi G, Cocchi D. Invited review: dairy intake and bone health: a viewpoint from the state of the art. J Dairy Sci 2011; 94:5249-62.

12. Heaney RP. Calcium, dairy products and osteoporosis. J Am Coll Nutr 2000; 19 Suppl 2:83S-99S

13. Muniz LC, Menezes AM, Assunção MC, Wehrmeister FC, Martínez-Mesa J, Gonçalves H, et al. Breastfeeding and bone mass at the ages of 18 and 30: prospective analysis of live births from the Pelotas (Brazil) 1982 and 1993 cohorts. PLoS One 2015; 10:e0122759.

14. Jones G, Hynes KL, Dwyer T. The association between breastfeeding, maternal smoking in utero, and birth weight with bone mass and fractures in adolescents: a 16-year longitudinal study. Osteoporos Int 2013; 24:1605-11.

15. Mølgaard C, Larnkjaer A, Mark AB, Michaelsen KF. Are early growth and nutrition related to bone health in adolescence? the Copenhagen Cohort Study of infant nutrition and growth. Am J Clin Nutr 2011; 94 Suppl 6:1865S-9S.

16. Rizzoli R, Bianchi ML, Garabédian M, McKay HA, Moreno LA. Maximizing bone mineral mass gain during growth for the prevention of fractures in the adolescents and the elderly. Bone 2010; 46:294-305.

17. Rizzoli R. Dairy products, yogurts, and bone health. Am J Clin Nutr 2014; 99 Suppl 5:1256S-62S.

18. Black RE, Williams SM, Jones IE, Goulding A. Children who avoid drinking cow milk have low dietary calcium intakes and poor bone health. Am J Clin Nutr 2002; 76:675-80. 
19. Bounds W, Skinner J, Carruth BR, Ziegler P. The relationship of dietary and lifestyle factors to bone mineral indexes in children. J Am Diet Assoc 2005; 105:735-41.

20. Infante D, Tormo R. Risk of inadequate bone mineralization in diseases involving long-term suppression of dairy products. J Pediatr Gastroenterol Nutr 2000; 30:310-3.

21. Rockell JE, Williams SM, Taylor RW, Grant AM, Jones IE, Goulding A. Two-year changes in bone and body composition in young children with a history of prolonged milk avoidance. Osteoporos Int 2005; 16:1016-23.

22. Huncharek M, Muscat J, Kupelnick B. Impact of dairy products and dietary calcium on bone-mineral content in children: results of a meta-analysis. Bone 2008; 43:312-21.

23. Winzenberg T, Shaw K, Fryer J, Jones G. Effects of calcium supplementation on bone density in healthy children: meta-analysis of randomised controlled trials. BMJ 2006; 333:775.

24. Mouratidou T, Vicente-Rodriguez G, GraciaMarco L, Huybrechts I, Sioen I, Widhalm K, et al. Associations of dietary calcium, vitamin D, milk intakes, and 25-hydroxyvitamin $\mathrm{D}$ with bone mass in Spanish adolescents: the HELENA study. J Clin Densitom 2013; 16:110-7.

25. Vatanparast H, Baxter-Jones A, Faulkner RA Bailey DA, Whiting SJ. Positive effects of vegetable and fruit consumption and calcium intake on bone mineral accrual in boys during growth from childhood to adolescence: the University of Saskatchewan Pediatric Bone Mineral Accrual Study. Am J Clin Nutr 2005; 82:700-6.

26. Whiting SJ, Vatanparast H, Baxter-Jones A, Faulkner RA, Mirwald R, Bailey DA. Factors that affect bone mineral accrual in the adolescent growth spurt. J Nutr 2004; 134:696S$700 \mathrm{~S}$.

27. Bischoff-Ferrari HA, Dawson-Hughes B, Baron JA, Kanis JA, Orav EJ, Staehelin HB, et al. Milk intake and risk of hip fracture in men and women: a meta-analysis of prospective cohort studies. J Bone Miner Res 2011; 26:833-9.

28. Kanis JA, Johansson H, Oden A, De Laet C, Johnell O, Eisman JA, et al. A meta-analysis of milk intake and fracture risk: low utility for case finding. Osteoporos Int 2005; 16:799-804.

29. Bolland MJ, Leung W, Tai V, Bastin S, Gamble GD, Grey A, et al. Calcium intake and risk of fracture: systematic review. BMJ 2015; 351:h4580.

30. Tai V, Leung W, Grey A, Reid IR, Bolland MJ. Calcium intake and bone mineral density: systematic review and meta-analysis BMJ 2015; 351:h4183.

31. Kontogianni MD, Yiannakouris N. Diet and bone health: the perspective of dietary pattern analysis. Eur Musculoskelet Rev 2009; 4:73-4.

32. Rizzoli R, Bonjour JP, Chevalley T. Dietary protein and bone mass accrual. In: Burckhardt $\mathrm{P}$, Dawson-Hughes B, Weaver C, editors. Nutritional influences on bone health. London: Springer; 2010. p. 1-8.
33. Monjardino T, Lucas R, Ramos E, Barros H. Associations between a priori-defined dietary patterns and longitudinal changes in bone mineral density in adolescents. Public Health Nutr 2014; 17:195-205.

34. Victora CG, Hallal PC, Araújo CLP, Menezes AMB, Wells JCK, Barros FC. Cohort profile: the 1993 Pelotas (Brazil) birth cohort study. Int J Epidemiol 2008; 37:704-9.

35. Gonçalves H, Assunção MCF, Wehrmeister FC, Oliveira IO, Barros FC, Victora CG, et al. Cohort profile update: the 1993 Pelotas (Brazil) birth cohort follow-up visits in adolescence. Int J Epidemiol 2014; 43:1082-8.

36. Gonçalves H, Wehrmeister FC, Assunção MCF, Tovo-Rodrigues L, Oliveira IO, Murray J, et al. Cohort profile update: the 1993 Pelotas (Brazil) birth cohort follow-up at 22 years. Int J Epidemiol 2018; 47:1389-90.

37. Schneider BC, Motta JVS, Muniz LC, Bielemann RM, Madruga SW, Orlandi SP, et al. Desenho de um questionário de frequência alimentar digital autoaplicado para avaliar o consumo alimentar de adolescentes e adultos jovens: coortes de nascimentos de Pelotas, Rio Grande do Sul. Rev Bras Epidemiol 2016; 19:419-32.

38. Núcleo de Estudos e Pesquisas em Alimentação, Universidade Estadual de Campinas. Tabela brasileira de composição de alimentos. 4a Ed. Campinas: Núcleo de Estudos e Pesquisas em Alimentação, Universidade Estadual de Campinas; 2011.

39. U.S. Department of Agriculture, Agricultural Research Service, USDA Nutrient Data Laboratory. USDA National nutrient database for standard reference, release 24. https:// www.ars.usda.gov/ARSUserFiles/80400525/ Data/SR24/sr24_doc.pdf (accessed on 03/ Nov/2017).

40. Hallberg L, Hulthén L. Prediction of dietary iron absorption: an algorithm for calculating absorption and bioavailability of dietary iron. Am J Clin Nutr 2000; 71:1147-60.

41. Oxalate.org. Oxalate (oxalic acid) content of $750+$ foods, with numbers from university and government sources. http://oxalate.org/ (accessed on 03/Nov/2017).

42. Wirfält E, Drake I, Wallström P. What do review papers conclude about food and dietary patterns? Food Nutr Res 2013; 57:20523.

43. Newby PK, Tucker KL. Empirically derived eating patterns using factor or cluster analysis: a review. Nutr Rev 2004; 62:177-203.

44. Cattell RB. The scree test for the number of factors. Multivariate Behav Res 1966; 1:24576.

45. Hu FB. Dietary pattern analysis: a new direction in nutritional epidemiology. Curr Opin Lipidol 2002; 13:3-9.

46. Craig CL, Marshall AL, Sjöström M, Bauman AE, Booth ML, Ainsworth BE, et al. International physical activity questionnaire: 12 -country reliability and validity. Med Sci Sports Exerc 2003; 35:1381-95. 
47. Pate RR, Pratt M, Blair SN, Haskell WL, Macera CA, Bouchard C, et al. Physical activity and public health. a recommendation from the Centers for Disease Control and Prevention and the American College of Sports Medicine. JAMA 1995; 273:402-7.

48. Leonard MB, Elmi A, Mostoufi-Moab S, Shults J, Burnham JM, Thayu M, et al. Effects of sex, race, and puberty on cortical bone and the functional muscle bone unit in children, adolescents, and young adults. J Clin Endocrinol Metab 2010; 95:1681-9.

49. Alswat KA. Gender disparities in Osteoporosis. J Clin Med Res 2017; 9:382-7.

50. Weaver CM, Gordon CM, Janz KF, Kalkwarf HJ, Lappe JM, Lewis R, et al. The National Osteoporosis Foundation's position statement on peak bone mass development and lifestyle factors: a systematic review and implementation recommendations. Osteoporos Int 2016; 27:1281-386.

51. Burckhardt P. Calcium revisited, part III: effect of dietary calcium on BMD and fracture risk. Bonekey Rep 2015; 4:708.

52. Lappe JM, Watson P, Gilsanz V, Hangartner T, Kalkwarf HJ, Oberfield S, et al. The longitudinal effects of physical activity and dietary calcium on bone mass accrual across stages of pubertal development. J Bone Miner Res 2015; 30:156-64.

53. Carter LM, Whiting SJ, Drinkwater DT, Zello GA, Faulkner RA, Bailey DA. Self-reported calcium intake and bone mineral content in children and adolescents. J Am Coll Nutr 2001; 20:502-9.

54. Lee KJ, Kim KS, Kim HN, Seo JA, Song SW. Association between dietary calcium and phosphorus intakes, dietary calcium/phosphorus ratio and bone mass in the Korean population. Nutr J 2014; 13:114.

55. Lloyd T, Chinchilli VM, Johnson-Rollings N, Kieselhorst K, Eggli DF, Marcus R. Adult female hip bone density reflects teenage sportsexercise patterns but not teenage calcium intake. Pediatrics 2000; 106:40-4.

56. U.S. Department of Health and Human Services; U.S. Department of Agriculture. 20152020 dietary guidelines for Americans. 8th Ed. http://health.gov/dietaryguidelines/2015/ guidelines/.(accessed on 03/Nov/2017).

57. Radominski SC, Bernardo W, Paula AP, Albergaria B, Moreira C, Fernandes CE, et al. Diretrizes brasileiras para o diagnóstico e tratamento da osteoporose em mulheres na pósmenopausa. Rev Bras Reumatol 2017; 57 Suppl 2:S452-66

58. World Health Organization. Diet, nutrition and the prevention of chronic diseases. Geneva: World Health Organization; 2003.

59. Yang Q, Lin SL, Au Yeung SL, Kwok MK, Xu L, Leung GM, et al. Genetically predicted milk consumption and bone health, ischemic heart disease and type 2 diabetes: a Mendelian randomization study. Eur J Clin Nutr 2017; 71:1008-12.
60. Moskal A, Pisa PT, Ferrari P, Byrnes G, Freisling $\mathrm{H}$, Boutron-Ruault MC, et al. Nutrient patterns and their food sources in an International Study Setting: report from the EPIC study. PLoS One 2014; 9:e98647.

64. World Health Organization; Food and Agriculture Organization of the United Nations. Preparation and use of food based dietary guidelines. Geneva: World Health Organization; 1998.

62. Tucker KL, Chen H, Hannan MT, Cupples LA, Wilson PW, Felson D, et al. Bone mineral density and dietary patterns in older adults: the Framingham Osteoporosis Study. Am J Clin Nutr 2002; 76:245-52.

63. Okubo H, Sasaki S, Horiguchi H, Oguma E, Miyamoto K, Hosoi Y, et al. Dietary patterns associated with bone mineral density in premenopausal Japanese farmwomen. Am J Clin Nutr 2006; 83:1185-92.

64. Kontogianni MD, Melistas L, Yannakoulia M, Malagaris I, Panagiotakos DB, Yiannakouris N. Association between dietary patterns and indices of bone mass in a sample of Mediterranean women. Nutrition 2009; 25:165-71.

65. Benetou V, Orfanos P, Pettersson-Kymmer U, Bergström U, Svensson O, Johansson I, et al. Mediterranean diet and incidence of hip fractures in a European cohort. Osteoporos Int 2013; 24:1587-98.

66. Zeng FF, Xue WQ, Cao WT, Wu BH, Xie HL, Fan F, et al. Diet-quality scores and risk of hip fractures in elderly urban Chinese in Guangdong, China: a case-control study. Osteoporos Int 2014; 25:2131-41.

67. Movassagh EZ, Vatanparast H. Current evidence on the association of dietary patterns and bone health: a scoping review. Adv Nutr 2017; 8:1-16.

68. Ferreira PM, Papini SJ, Corrente JE. Diversity of eating patterns in older adults: a new scenario? Rev Nutr 2014; 27:67-9.

69. Cade J, Thompson R, Burley V, Warm D. Development, validation and utilisation of foodfrequency questionnaires: a review. Public Health Nutr 2002; 5:567-87.

70. Cade JE, Burley VJ, Warm DL, Thompson RL, Margetts BM. Food frequency questionnaires: a review of their design, validation and utilisation. Nutr Res Rev 2004; 17:5-22.

71. Aloia JF, Dhaliwal R, Shieh A, Mikhail M, Fazzari M, Ragolia L, et al. Vitamin D supplementation increases calcium absorption without a threshold effect. Am J Clin Nutr 2014; 99:62431.

72. Brix N, Ernst A, Lauridsen LLB, Parner E, Støvring H, Olsen J, et al. Timing of puberty in boys and girls: a population-based study. Paediatr Perinat Epidemiol 2019; 33:70-8.

73. Cumpian-Silva J, Rinaldi AEM, Mazzeti CMS, Conde WL. Fenótipos corporais na adolescência e a maturação sexual. Cad Saúde Pública 2018; 34:e0057217. 


\section{Resumo}

O estudo teve como objetivo avaliar o consumo de leite, a ingestão dietética de cálcio e os padrões de nutrientes (favoráveis e desfavoráveis à saúde óssea) do final da adolescência até o início da idade adulta sobre a massa óssea aos 22 anos de idade. Foram realizadas análises transversais em 3.109 participantes da coorte de nascimentos de 1993 de Pelotas, Rio Grande do Sul, Brasil, nos acompanhamentos realizados aos 18 e 22 anos de idade. Aos 22 anos, foi avaliada a densidade mineral óssea (DMO) da coluna lombar, do fêmur direito e do corpo inteiro, utilizando absorciometria de raios- $x$ de dupla energia (DXA). As variáveis de exposição (cálcio dietético, leite e padrões de nutrientes) foram criadas pela combinação das frequências de consumo entre os dois acompanhamentos (sempre baixo, moderado, sempre alto, aumentado ou diminuído). Foram realizadas análises de regressão linear múltipla, estratificadas por sexo. No fêmur direito, homens classificados nas categorias de consumo de leite "sempre alto" ( $m e ́ d i a=1,148 \mathrm{~g} / \mathrm{cm}^{2}$; IC95\%: 1,116; 1,181) e "aumentado" (média = $1,154 \mathrm{~g} / \mathrm{cm}^{2}$; IC95\%: 1,$\left.135 ; 1,174\right)$ apresentaram DMO ligeiramente baixa, comparado com as categorias de consumo "sempre baixo" (média $=1,190$ g/cm²; IC95\%: 1, 165; 1,215) e "moderado" (média = 1,191g/ $\mathrm{cm}^{2}$; IC95\%: 1,171; 1,210). Além disso, os homens sempre classificados no tercil mais alto do padrão "favorável à saúde óssea" apresentaram a média mais baixa de DMO de corpo inteiro (média $=1,254 \mathrm{~g} / \mathrm{cm}^{2}$; IC95\%: 1,243; 1,266). Não foram observadas associações entre as categorias de ingestão de cálcio dietético e do padrão "favorável à saúde óssea" e cada um dos três desfechos de DMO. Os resultados corroboram o fato de que dietas constituídas de alimentos e nutrientes inibidores podem afetar negativamente a saúde óssea.

Densidade Óssea; Absorciometria de Fóton Duplo; Leite; Cálcio; Dieta

\section{Resumen}

El objetivo de este estudio es evaluar el efecto del consumo de leche, ingesta dietética de calcio y patrones nutricionales (beneficiosos y no beneficiosos para los huesos), desde la adolescencia tardía hasta la etapa adulta temprana, en huesos con 22 años de edad. Se realizó un análisis transversal con 3.109 participantes procedentes de la cohorte de nacimiento de 1993 en Pelotas, Rio Grande do Sul, Brasil, con seguimientos a los 18 y 22 años de edad. Se evaluó la densidad mineral ósea de la columna lumbar, fémur derecho $y$ todo el cuerpo a los 22 años, utilizando densitometría ósea por absorción de rayos $X(D X A)$. Las variables de exposición (calcio dietético, leche $y$ patrones nutricionales) se crearon mediante la combinación de las frecuencias de consumo entre los dos seguimientos (siempre bajo, moderado, alto, incremento o disminución). Se realizaron regresiones múltiples lineales, estratificadas por sexo. En la zona del fémur derecho, los hombres fueron clasificados en "siempre alto" (media = 1,148g/cm²; IC95\%: 1,116; 1,181) e "incrementado" en las categorías de consumo de leche (media = $1,154 \mathrm{~g} / \mathrm{cm}^{2}$; IC95\%: 1,$\left.135 ; 1,174\right)$ presentó una ligeramente baja densidad mineral ósea (DMO), comparándolas con las categorías bajas (media = $1,190 \mathrm{~g} / \mathrm{cm}^{2}$; IC95\%: 1,165; 1,215) y moderadas $\left(\right.$ media $=1,191 \mathrm{~g} / \mathrm{cm}^{2} ;$ IC95\%: 1,171; 1,210). Asimismo, los hombres siempre fueron clasificados en el tercil más alto del patrón "no beneficioso para los huesos", puesto que presentaron la media más baja de todo el cuerpo de DMO (media = 1,254g/cm²; IC95\%: 1,243; 1,266). No se observaron asociaciones entre las categorías de ingesta de calcio dietético y los patrones "beneficiosos para los huesos" en cada uno de los tres resultados de DMO. Estos resultados indican el hecho de que las dietas que inhiben alimentos/nutrientes pueden contribuir negativamente en la salud de los huesos.

Densidad Ósea; Absorciometría de Fotón Dual Análisis; Leche; Calcio; Dieta
Submitted on $03 /$ Oct $/ 2018$

Final version resubmitted on 18/Mar/2019

Approved on 29/Mar/2019 